\title{
Heidi Lehtovaara
}

\section{Korkeasti koulutettujen maahanmuuttaneiden naisten kokemuksia työnhakuvaiheen syrjinnästä}

\section{Tiivistelmä}

Korkeasti koulutetut maahanmuuttaneet naiset kohtaavat syrjivää kohtelua niin arkisissa kohtaamisissa, työnhakuvaiheessa kuin työelämässä. Tarkastelen artikkelissani laadullisen tutkimuksen keinoin, millaisia syrjinnän ja rasismin kokemuksia aineistosta nousi esiin ja millaisia strategioita haastateltavat kuvasivat käyttäneensä syrjintää ja rasismia kohdatessaan. Hyödynnän sukupuolentutkimuksen ja työelämän tutkimuksen teoriakeskusteluja. Kutsuin tutkimukseen 12 haastateltavaa, jotka edustavat monipuolisesti EU:n alueelta sekä sen ulkopuolelta muuttaneita. Tiedonkeruumenetelmänä käytin teemahaastattelua ja analyysimenetelmänä sisällönanalyysiä. Tulosten mukaan rasismia esiintyi jo ennen varsinaista työnhakuprosessia. Syrjintäkokemukset vaikeuttivat ja pitkittivät työnhakuprosessia. Strategiat syrjintää ja rasismia kohdatessa vaihtelivat yksilöllisesti, ja niitä myös vaihdeltiin tilannekohtaisesti. Pitkittynyt työnhakuprosessi ja sitä vaikeuttava syrjivä kohtelu vaikutti kielteisesti yksilön hyvinvointiin, työllistymiseen sekä työuran kehittymiseen. Artikkelin lopuksi esitän kehittämisehdotuksia rekrytointivaiheen syrjinnän vähentämiseksi. 


\section{Johdanto}

Tarkastelen artikkelissani korkeasti koulutettujen maahanmuuttaneiden naisten työnhakuvaiheessa kohtaamaa syrjivää kohtelua. Syrjinnän ja rasismin kokemusten esiin nostaminen laadullisen tutkimuksen keinoin on tärkeää, koska sen myötä ilmiön mekanismeja tehdään näkyviksi ja niihin puuttumisen toimintamalleja kehitetään tehokkaammiksi (myös Seikkula \& Hortelano 2021). Osallistun artikkelillani keskusteluun korkeasti koulutettujen maahanmuuttaneiden naisten työelämäintegraatiosta. Aihetta on tarkasteltu Suomessa 2000-luvulla Suomen Akatemian rahoittamissa hankkeissa (esim. WeAll ${ }^{1}$ ja Polkuja työhön ${ }^{2}$ ), raporteissa (esim. Kazi ym. 2019; Yijälä \& Luoma 2018) sekä tutkimuksissa (esim. Davydova 2012; Habti \& Koikkalainen 2013; Kyhä 2011; Steel \& Jyrkinen 2017). Pohjoismaissa korkeasti koulutettujen työelämäintegraatiota ovat tarkastelleet esimerkiksi Irastorza ja Bevelander (2021) sekä Aure (2013) ja erityisesti naisten tilannetta Fossland (2013) sekä Liversage (2009). Esittelen aluksi tutkimuksen peruskäsitteet, tutkimuskysymykset sekä teoreettiset lähtökohdat. Tämän jälkeen kuvaan tutkimuksen toteutusta ja tuloksia. Johtopäätösten ja pohdintaosuuden jälkeen esitän kehittämisehdotuksia.

Käytän käsitettä maahanmuuttanut tarkoittamaan nuoruus- tai aikuisiällä Suomeen muuttanutta henkilöä, jonka äidinkieli on muu kuin suomi, ruotsi tai saame. Korkeasti koulutetulla viittaan henkilöön, jolla on ammattikorkeakoulu- tai yliopistotutkinto. Korkeasti koulutetut maahanmuuttaneet mielletään usein ensisijaisesti EU:n alueelta muuttaviksi ja korkean sosioekonomisen statuksen omaaviksi (Koskela 2020). Suomeen muuttaa kuitenkin korkeasti koulutettuja monista eri maista ja syistä, kuten vapaaehtoisesti opintojen ja perheen vuoksi. Pakkomuutoksi kutsutaan pakolais- ja turvapaikkastatuksella toteutuvaa muuttoa (Korkiasaari \& Söderling 2007). Usein muuttosyitä on useampia.

Suomeen muuttavien ammatillista sijoittumista kehystävät työmarkkinoiden rakenteet, työvoiman kysyntä ja tarjonta (Haapakorpi 2007, 213) sekä taloudellinen suhdannevaihtelu. Työmarkkinat ovat Suomessa muiden Pohjoismaiden tapaan segregoituneet (Mustosmäki ym. 2021, 5). Työllistymiseen vaikuttavat useat tekijät, kuten lähtömaa, muuton ajankohta ja syy(t), koulutus, ammatti, sukupuoli ja ikä

\footnotetext{
1 http://weallfinland.fi/

2 http://www.polkujatyohon.fi/ tietoja-hankkeesta/
} 
(Busk ym. 2016, 60-61). Vaikeimmin työllistyvien ryhmään kuuluvat pakolais- ja turvapaikkastatuksella muuttavat (Grönlund \& Nordlund 2021; Irastorza \& Bevelander 2021). Maahanmuuttaneiden työurat ovat usein pirstaleisia, ja myös korkeasti koulutettu voi joutua aloittamaan työuransa Suomessa niin sanotuista sisääntulotöistä (Haapakorpi 2007).

Suomeen muuttavista naisista lähes 70 prosenttia muuttaa tänne perhesyistä. Naiset ovat maahanmuuttaneita miehiä koulutetumpia (Larja 2019), mutta heidän työllisyysasteensa on alhainen verrattuna sekä maahanmuuttaneisiin miehiin että maahanmuuttaneisiin naisiin muissa Pohjoismaissa (Kurronen 2021). Tähän vaikuttaa osin maiden erilainen väestörakenne sekä hitaampi pääsy työvoimapalveluihin Suomessa (Larja 2019). Naisten matalaa työllisyysastetta selittää myös alle 18-vuotiaiden lasten äitien heikko työllistyminen (OECD 2018). Ero on suurin perusasteen varassa olevilla äideillä mutta merkittävä myös korkeasti koulutetuilla (Larja 2021). Maahanmuuttoprosessin myötä naisten rooli hoivavastuunkantajina voi korostua entisestään (Fossland 2013, 279; Grönlund \& Nordlund 2021, 3; Mustosmäki ym. $2021,6)$. Pienten lasten äitinä maahan muuttava voi joutua tilanteeseen, jossa kotoutumisajan suomen kielen kurssit menevät ohi, eikä ammatillisia verkostoja pääse arjessa rakentamaan (Lehtovaara \& Säppi 2021, 51). Perheellisten naisten heikko työmarkkina-asema siirtyy eteenpäin seuraavalle sukupolvelle, erityisesti tyttärille (Kurronen 2021).

Tutkimuskysymykseni ovat seuraavat:

1. Millaisia syrjinnän ja rasismin kokemuksia aineistosta nousi esiin?

2. Miten haastateltavat kertoivat reagoineensa syrjivään kohteluun?

3. Millaisia strategioita he kuvasivat käyttäneensä kohdattuaan syrjintää ja rasismia?

\section{Teoreettiset lähtökohdat}

\section{Intersektionaalisuus ja risteävät erot}

Maahanmuuttaneiden kotoutumisen edistämistä on tärkeää tarkastella rakenteelliset valtasuhteet huomioivassa kontekstissa, koska jo oleskelulupakategorioiden määrittämät rajalliset oikeudet sekä epävarma vaihe ennen pysyvän oleskeluluvan saamista muokkaavat yksilöiden asemaa myös työmarkkinoilla. EU:n sisältä ja EU:n 
ulkopuolelta muuttavien oikeudellinen asema on erilainen, mikä vaikuttaa työnhakuun (Könönen 2011; Maury 2020). Työn perusteella Suomeen muuttavat ovat niin ikään erilaisessa asemassa riippuen tehtävästä työstä ja palkasta (Könönen \& Himanen 2019, 56).

Maahanmuutto on myös sukupuolittunut prosessi (Nardon ym. 2021), ja prosessiin liittyviä vallan ja epätasa-arvoisuuksien mekanismeja on tärkeä nostaa tutkimuksen kohteeksi (McCall 2005, 1775). Sukupuoli on perinteisesti käsitetty sukupuolieron kautta, jolloin eron juurten nähdään olevan anatomiassa ja fysiologiassa. Butlerin (2006) teoria sukupuolen performatiivisuudesta sen sijaan korostaa, että sukupuoli on eleitä, tekoja ja toistotekoja. Sukupuolta tuotetaan toiminnan ja käytäntöjen kautta elämän eri alueilla, kuten työelämässä.

Myös työnhakukokemusten analyysi edellyttää kontekstitietoista lähestymistapaa, joka ottaa huomioon epätasa-arvon monipohjaisuuden (Wrede 2010, 23). Tästä syystä näkökulmani on intersektionaalinen. Crenshaw`n (1989) mukaan intersektionaalisuus pureutuu eri kategorioiden välisiin suhteisiin ja siihen, miten kategoriat rakentavat toisiaan ja tuottavat yhdessä erilaisia positioita ja identiteettejä yksittäisille ihmisille ja ryhmille. Tutkimuksessa tulee huomioida Euroopan ulkopuolelta lähtöisin olevien naisten tilanne sekä yleisesti kokemusten heterogeenisuus (Bastia 2014, 239).

Suomen kielestä puuttuu vielä sanasto, jolla kuvata ei-valkoisia. Käsitteelle Person/ People of Color (PoC) ei ole neutraalia vastinetta (Seikkula \& Keskinen 2021, 10, 16). Rodullistamisella ${ }^{3}$ viittaan merkityksenannon prosessiin, jossa ihmisiä luokitellaan hierarkkisesti kulttuurisissa ja yhteiskunnallisissa käytännöissä. Hierarkkista rodullistamisen prosessia määrittää valkoisuus, joka ei tarkoita vain ihonväriä. Se viittaa useista piirteistä koostuvaan normiin ja ideaaliin, johon nähden rodullistavia erotteluja tehdään.

\section{Rekrytointisyrjinnän tutkimus}

Suomen lainsäädännössä (Suomen perustuslaki; Laki naisten ja miesten välisestä tasa-arvosta; Työsopimuslaki; Yhdenvertaisuuslaki) määritellään työelämässä

\footnotetext{
3 Termiä käytti alun perin koloniaalien valtasuhteiden teoretisoinnista tunnettu Frantz Fanon (Seikkula \& Hortelano 2021, 148).
} 
kielletyt syrjintäperusteet. Syrjintää eli henkilön tai ryhmän eriarvoista kohtelua tai erilaiseen asemaan asettamista ilman hyväksyttävää syytä kohtaavat erityisesti vähemmistöt (esim. Bertrand \& Mullainathan 2004). Arjen rasismin käsitteen kehittäneen Essedin (1991) mukaan ilmiössä on kyse ryhmien välisiin voimasuhteisiin liittyvästä vallankäytöstä, jossa rasistiset käsitykset rakentuvat osaksi toistuvia, arkipäiväisiä merkityksenannon käytäntöjä - esimerkiksi puhuttu kieli, uskonnollisesta vakaumuksesta kertova pukeutuminen tai ihonväri tulkitaan yhä uudelleen merkiksi henkilön muista, olemuksellisista ominaisuuksista (Seikkula \& Hortelano 2021, 148-149).

Työnhakuvaiheessa kohdattu syrjintä on vaikeasti tavoitettava ilmiö. Työnhaussa menestymiseen tarvitaan ammatillisia verkostoja ja kohdemaan työnhakukäytäntöjen tuntemusta. FinMonik-tutkimuksen (Kuusio ym. 2020) mukaan yksi yleisimmin koettu työllistymisen este on verkostojen puuttuminen Suomessa syntyneiden kanssa. Tämä voi olla syrjinnän ilmentymä (Ahmad 2010).

Suuri osa työnhakuvaiheen syrjinnästä tapahtuu jo ennen haastattelua tai eri vaiheissa rekrytointiprosessia (Aalto ym. 2010, 10-11). Rekrytointia on tutkittu Suomessa runsaasti työnantajanäkökulmasta, ja rekrytointi nähdään usein suoraviivaisena prosessina (Huilaja 2019). Tässä artikkelissa puhun myös työnhausta prosessina. Prosessimaisuus viittaa erilaisten vaiheiden runsauteen ja ajallisesti epämääräiseen kestoon.

Jo työpaikkailmoituksen kieli sekä työpaikasta ilmoittamisen kanavat (ks. Huilaja 2019) vaikuttavat siihen, kuka saa informaatiota avoimesta tehtävästä. Syrjintä voi olla välitöntä, jolloin henkilöä kohdellaan syrjivän syyn perusteella epäsuotuisammin kuin toista vastaavassa tilanteessa olevaa. Välillisessä syrjinnässä tasapuoliselta näyttävä säännös, peruste tai käytäntö johtaa henkilön joutumiseen syrjivän syyn perusteella epäedulliseen asemaan muihin nähden. Moniperusteinen syrjintä ${ }^{4}$ tarkoittaa syrjinnän kohteeksi joutumista kahden tai useamman eri ominaisuuden perusteella (Oikeusministeriö 2019).

\footnotetext{
4 Moniperusteisesta syrjintää kuvataan myös moninkertaisen, kumulatiivisen ja risteävän syrjinnän käsitteiden avulla. Moninkertaiseksi syrjinnäksi kutsutaan tilannetta, jossa henkilö kohtaa syrjintää useammassa kuin yhdessä tilanteessa eri perusteilla. Kumulatiivisessa syrjinnässä yksilö kokee syrjintää samassa tilanteessa useammalla perusteella. Risteävässä syrjinnässä eri perusteet risteävät ja läpileikkaavat toisensa ja siten yhdessä muodostavat erityisen syrjintäperusteen (Oikeusministeriö 2019, 4).
} 
Rekrytointisyrjintää on usein vaikea todentaa. Sitä voi edustaa tilanne, jossa työnantaja jättää pätevän hakijan kutsumatta työhaastatteluun (Ahmad 2010). Erinomaisen suomen kielen taidon edellyttämisen taustalle voi kätkeytyä syrjintää (Rask ym. 2018). Suomessa syntyneistä rekrytointisyrjintää kohtaavat erityisesti romanit (Oikeusministeriö 2021) sekä näkyvään vähemmistöön (visible minorities) kuuluvat, esimerkiksi afrosuomalaiset (FRA 2017). Maahanmuuttaneiden syrjintä työnhakuvaiheessa on yleistä (Aalto ym. 2010; Ahmad 2019; Jasinskaja-Lahti ym. 2002; Kanninen \& Virkola 2021; Larja ym. 2012; Liebkind ym. 2016), ja sitä kohtaavat eniten Lähi-Idästä ja Afrikasta muuttavat (Könönen \& Himanen 2019). Ahmadin (2019) kenttäkoe osoitti, että maahanmuuttajataustaiset hakijat saavat kutsuja työhaastatteluihin merkittävästi Suomessa syntyneitä vähemmän, vaikka heidän henkilökohtaiset ominaisuutensa (kuten ikä, koulutus, työkokemus ja ammatillinen tutkinto) ovat täysin samat. Tutkimus osoitti myös etnisen hierarkian yleisyyden: työnantajat ovat ennakkoluuloisempia Euroopan ulkopuolelta muuttaneita kohtaan.

Maahanmuuttotaustaan ja sukupuoleen liittyvää tutkimusta tarvitaan lisää, koska naisilla on yleisesti enemmän työhönottovaiheeseen liittyviä syrjintäkokemuksia (Pietiläinen ym. 2016, 52). Naiset kokevat syrjintää erityisesti hakiessaan korkean statuksen työpaikkoihin (Mustosmäki ym. 2021, 5). Sukupuoleen kohdistuva rekrytointisyrjintä on myös alakohtaista - naisia syrjitään heidän hakiessaan miesvaltaisiin tehtäviin ja miehiä heidän hakiessaan naisvaltaisiin tehtäviin. Syrjinnän ja rasismin ilmenemismuotojen tutkiminen on tärkeää, koska niillä on vakavia seurauksia yksilön taloudelliselle tilanteelle, hyvinvoinnille ja työurien käynnistymiselle sekä pituudelle (Pietiläinen ym. 2018; Polanco-Roman ym. 2016; Rask ym. 2018).

Sovellan tutkimusaineistoni analyysissä Lazaruksen ja Folkmanin (1984) kognitiivisen arvioinnin viitekehystä. Yksilön kokemus siitä, onko hän kohdannut syrjintää vai ei, liittyy kiinteästi uhan arviointiin. Syrjinnän kohteeksi joutuvan on päätettävä, reagoiko hän ja mitä strategioita hän käyttää. Reagoimisen strategiat voidaan jakaa suoriin (konfrontoiviin) ja vältteleviin (Noh ym. 1999). Toisen jaon mukaan strategioita voidaan pitää hyökkäävinä (assertiivisina), ei-hyökkäävinä tai psyykkisinä (Swim ym.1998). Suorissa tai hyökkäävissä reaktioissa syrjinnän kohde tuo avoimesti esille epämiellyttävän olotilansa syrjinnän aiheuttajalle joko sanallisesti tai fyysisellä toiminnalla tai ilmoittaa tapahtuneesta viranomaiselle. Välttelevät (ei-hyökkäävät) ja psyykkiset reaktiot sisältävät kokemusten passiivista hyväksyntää tai epäsuoraa reagointia niihin. Ei-hyökkäävät reaktiot voivat sisältää epäsuoria viestejä (esim. 
ironia), kiusaajan tyynnyttelyä tai epäsuoraa vihamielisyyttä. Psyykkiset reaktiot voidaan jakaa tunnereaktioihin (turhautuminen, viha, ahdistus, masentuneisuus, fyysiset oireet) sekä hallintakeinoihin (syrjinnän syiden näkeminen itsensä ulkopuolella, kieltäminen, torjuminen). Olen ensisijaisesti kiinnostunut siitä, miten haastateltavat kuvasivat reaktioitaan ja käyttämiään strategioita kohdattuaan syrjintää ja rasismia työnhakuvaiheessa.

\section{Tutkimuksen toteutus}

Artikkelissa esiteltävät tulokset pohjautuvat tekeillä olevan tutkimukseni ensimmäisen aineiston analyysiin. Aineisto (taulukko 1) on kerätty pääosin vuosina 20162018 ja koostuu 12 Suomeen muuttaneen naisen haastattelusta. Löysin haastateltavat työelämäverkostojeni kautta. Kriteereinä haastateltavien valinnalle olivat maahanmuuttotaustan ohella korkea-asteen koulutus (ammattikorkeakoulututkinto, alempi tai ylempi yliopistotutkinto) sekä kokemus työnhausta Suomesta. Suuri osa haastateltavista oli haastatteluhetkellä mukana työelämässä osa-aikaisessa, määräaikaisessa tai pysyvässä työsuhteessa. Otin uudelleen yhteyttä haastateltaviin keväällä 2019 varmistaakseni, oliko heidän asemansa työmarkkinoilla muuttunut.

Haastatellut naiset edustavat monipuolisesti EU:n alueelta ja sen ulkopuolelta muuttaneita. Haastateltavien nimet on muutettu tunnistamisen välttämiseksi. Deborah, Ingrid, Janet, Olga ja Rebecca ovat muuttaneet Euroopasta, Aisha, Jemina, Maya ja Nora Afrikan mantereelta, Sonia ja Layla Lähi-Idästä sekä Anna Aasiasta. Kymmenellä naisella muutto Suomeen perustui vapaaehtoisuuteen syiden vaihdellessa aviopuolison vuoksi muuttamisesta toiveeseen taata lapsille laadukas suomalainen koulutus. Haastateltavista puolet tuli Suomeen itsenäisinä muuttajina. Anna ja Ingrid tulivat alun perin täydentämään opintojaan, mutta haastatteluhetkellä he olivat asuneet ja työskennelleet Suomessa jo pidemmän aikaa. Aisha ja Layla pakenivat sotaa - Aisha nuoruusiällä perheensä kanssa, Layla aikuisena lapsensa kanssa. Haastateltavat olivat muuttaneet Suomeen eri-ikäisinä kolmella eri vuosikymmenellä: 1990-, 2000- ja 2010-luvuilla. He edustavat monipuolisesti erilaisia koulutustaustoja ja ammattikuntia. Kotoutumisen kieleksi oli valittu suomi. Suurimmalla osalla (9/12) haastateltavista on lapsia (1-3). 
Keräsin aineiston puolistrukturoituina yksilöhaastatteluina, jotka nauhoitin ja litteroin. Haastattelurungon kysymykset koskivat työnhakuprosessiin liittyviä odotuksia ja kokemuksia sekä mahdollista syrjivää kohtelua. Aihepiirit oli ennalta määritelty, mutta niiden laajuus ja järjestys vaihtelivat eri haastatteluissa. Haastattelupaikkana toimivat kirjasto ja kahvila sekä yhdessä tapauksessa haastateltavan työpaikka. Kahdessa haastattelutilanteessa oli mukana myös haastateltavan lapsi tai lapsia. Toinen näistä haastatteluista jouduttiin keskeyttämään. Täydensin osaa haastatteluvastauksista jälkikäteen sähköpostitse. Ennen haastattelun aloittamista kerroin perusasiat tutkimuksestani. Haastateltavat täyttivät suostumuslomakkeet ja taustatietolomakkeet. Pyrin selvittämään työni tavoitteet ja korostin mahdollisuuttani olla käytettävissä tutkimusprosessini ajan.

Haastateltavat kertoivat, että heillä on hyvät tai erinomaiset digitaidot ja monipuolinen kielitaito. He puhuvat kolmesta viiteen kieltä. Oma äidinkieleni on suomi, ja noin puolet halusi vastata kysymyksiini suomeksi. Toiset halusivat vastata ensin suomeksi ja vaihtaa kielen välillä englanniksi (joka ei kuitenkaan välttämättä ollut haastateltavan äidinkieli). Suomeksi vastaaminen saattoi aiheuttaa ennakoimaani enemmän paineita. Työskenneltyäni vuosia maahanmuuttaneiden naisten työllistämiskysymysten parissa eri sektoreilla minulla on taustatietoa ilmiöstä. Haastattelujen toteuttamishetkellä olin kokopäivätyössä opintojeni ohella eli asemani työmarkkinoilla oli vakaa. Olen pyrkinyt huomioimaan nämä seikat tutkimusta tehdessäni, kuten myös minua ja haastateltavia yhdistävät tekijät (esimerkiksi koulutus, kokemus asiantuntijatyöstä, monipuolinen kielitaito, fyysinen terveys ja toimintakyky). Toisaalta olen syntynyt Suomessa ja tunnen maan koulutusjärjestelmän sekä työnhakukäytännöt. Nämä seikat ovat varmasti vaikuttaneet haastattelun aikana esiin nostettuihin aiheisiin. Tavoitteenani oli luoda haastatteluihin keskusteleva ilmapiiri edistääkseni vuorovaikutuksen tasavertaisuutta. Työnhakuvaiheessa kohdatut haasteet ja syrjintä ovat sensitiivisiä aiheita, joista on voitu haluta kertoa valikoiden tai vaieta kokonaan (ks. Pietiläinen ym. 2016). Sain kuitenkin vaikutelman, että tutkimukseni aihetta pidettiin tärkeänä ja työnhakuvaiheeseen liittyviä epäkohtia ja kehittämisehdotuksia haluttiin nostaa aktiivisesti esiin.

Valitsin sisällönanalyysin aineiston analyysimenetelmäksi, koska sen avulla on mahdollista kuvata ja analysoida dokumenttien sisältöä systemaattisesti sekä pyrkiä saamaan tutkittavasta ilmiöstä selkeä kuvaus. Sisällönanalyysi perustuu tulkintaan ja päättelyyn, jossa edetään empiirisestä aineistosta kohti käsitteellisempää näke- 
mystä tutkittavasta ilmiöstä (Tuomi \& Sarajärvi 2002). Miles ja Huberman (1994) korostavat, että aineistolähtöinen analyysi on kolmivaiheinen prosessi, joka koostuu aineiston redusoinnista (pelkistäminen), klusteroinnista (ryhmittely) sekä abstrahoinnista (teoreettisten käsitteiden luominen). Ensimmäisessä vaiheessa karsin aineistosta epäolennaisen, toisessa ryhmittelin aineistoa ja etsin samankaltaisuuksia tai eroavaisuuksia kuvaavia käsitteitä. Lopuksi erottelin tutkimuksen kannalta olennaista tietoa. Temaattisen tarkastelun jälkeen analysoin aineistoa keskittymällä sosiaalisiin kategorioihin (sukupuoli, maahanmuuttotausta). Sosiaalisista kategorioista puhuminen ei välttämättä ole yleistä, vaikka ne vaikuttavat monitasoisesti yksilön kokemuksiin (Steel \& Tuori 2016). Omankin aineistoni haastateltavat puhuivat sukupuolesta vähemmän eksplisiittisesti.

Olen pyrkinyt ymmärtämään tutkittavia heidän omasta näkökulmastaan analyysin kaikissa vaiheissa. Tuloksissa esitän aineistosta nousevia teemoja ja johtopäätöksissä pyrin tulkitsemaan, mitä asiat tutkittaville merkitsevät (ks. Tuomi \& Sarajärvi 2002, 127). Tutkimuksen aineistosta nousi esiin myös teemoja, joita en ollut osannut etukäteen ajatella. Haastateltavat kuvasivat esimerkiksi pitkittyneen työnhakuprosessin kielteisiä vaikutuksia parisuhteeseen sekä äidin rooliin Suomessa kohdistuvia paineita.

Taulukko 1. Haastateltavien perustiedot: lähtömaa, syntymävuosi, Suomeen muutto, koulutustausta ja muuttosyy

\begin{tabular}{|c|c|c|c|c|c|}
\hline $\begin{array}{l}\text { haastatel- } \\
\text { tava }\end{array}$ & lähtömaa & $\begin{array}{l}\text { syntymä- } \\
\text { vuosi }\end{array}$ & $\begin{array}{l}\text { Suomeen } \\
\text { muutto }\end{array}$ & koulutustausta & muuttosyy \\
\hline 1 Deborah & Eurooppa & 1970-luku & 2010-luku & yhteiskuntatiede & parisuhde \\
\hline 2 Rebecca & Eurooppa & 1980-luku & 2010-luku & sosiaaliala & lähtömaan työllisyystilanne \\
\hline 3 Olga & Eurooppa & 1970-luku & 2010-luku & sosiaaliala & parisuhde \\
\hline 4 Janet & Eurooppa & 1960-luku & 2000-luku & luonnontiede & puolison työ Suomessa \\
\hline 5 Ingrid & Eurooppa & 1970-luku & 1990-luku & taideala & opiskelu / muu syy \\
\hline 6 Nora & Afrikan mantere & 1970-luku & 1990-luku & sosiaaliala & perhesyy \\
\hline 7 Jemina & Afrikan mantere & 1970-luku & 1990-luku & IT-ala & muu syy \\
\hline 8 Maya & Afrikan mantere & 1970-luku & 2000-luku & kaupallinen ala & parisuhde \\
\hline 9 Aisha & Afrikan mantere & 1980-luku & 1990-luku & sosiaaliala & pakolaisstatus \\
\hline 10 Layla & Lähi-Itä & 1970-luku & 2000-luku & yhteiskuntatiede & pakolaisstatus \\
\hline 11 Sonia & Lähi-Itä & 1970-luku & 2010-luku & opetusala & lasten koulutus \\
\hline 12 Anna & Kaakkois- Aasia & 1980-luku & 2010-luku & sosiaaliala & opiskelu \\
\hline
\end{tabular}




\section{Tulokset}

Työnhaku Suomessa muodostui haastateltaville odotettua haastavammaksi ja pidemmäksi prosessiksi huolimatta koulutuksesta ja kokemuksesta sekä aktiivisesta sosiaalisen ja instrumentaalisen tuen hakemisesta (myös Lehtovaara \& Jyrkinen 2021). Odotusten ja kokemusten välistä ristiriitaa aiheuttivat tutkinnon rinnastamisen vaikeus, englanninkielisten työmarkkinoiden suppeus sekä kokemukset suomalaisten työnantajien korkeista suomen kielen vaatimuksista ja asenteellisuudesta (myös Ahmad 2010; Alho 2020). Pitkittyneellä työnhakuprosessilla kerrottiin olleen kielteisiä vaikutuksia taloudelliseen tilanteeseen, itsetuntoon, parisuhteeseen ja vanhemmuuteen. Deborah kertoi: Pitkä työnhakuaika ilman tuloksia sai minut tuntemaan itseni vähempi arvokkaaksi. Olen alkanut kyseenalaistaa itseni ja taitojani. Se aiheutti stressiä ja myös fyysisiä oireita - esim. minulla todettiin vatsahaava. Toisaalta muutama haastateltava korosti, että oli löytänyt itsestään uudenlaista voimaa ja taitoja työnhakuprosessin myötä. Omaa työmarkkina-asemaa oli pyritty kohentamaan aktiivisesti erilaisten strategioiden avulla - osallistumalla tuetun työllistämisen jaksolle (työkokeilu, palkkatuki) tai tekemällä vapaaehtoistyötä. Epäsäännöllisten työsuhteiden (projektitehtävät, käännöstyöt, tulkkaus) ja osa-aikaisen pienyrittäjyyden yhdistely oli tavallista, kuten myös lisäkoulutuksen tai kokonaan uuden koulutuksen hankkiminen.

\section{Työelämään ohjaamisen vaihe}

Suurin osa haastateltavista kertoi hakeneensa aktiivisesti instrumentaalista ja sosiaalista tukea työllistymiseen julkisten työvoimapalvelujen lisäksi kolmannen sektorin työllistämishankkeista sekä mentorointiohjelmista. Etenkin kolmannelta sektorilta saatua tietoa, sosiaalista tukea ja verkostoja pidettiin erityisen hyödyllisinä (myös Lehtovaara \& Jyrkinen 2021; Nardon ym. 2021). Kokemuksia julkisen sektorin palveluista sen sijaan kuvattiin pääosin negatiivisin sanakääntein (myös Steel \& Jyrkinen 2017). Haastateltavat kertoivat turhautumisestaan saatuaan ohjeita hakeutua koulutustaan vastaamattomille matalapalkka-aloille (myös Kurki 2018; Könönen \& Himanen 2019). Deborah muisteli kokemustaan: 
Ajattelin että hän [TE-palvelujen asiantuntija] ei ymmärtänyt mun tilannettani, mitä mä pystyn tekemään mitä en... Eli olin sitä mieltä että hän on vain ehdottanut jotain "by default" yleispätevä mitä hänet on ohjattu ehdottamaan. Kaikki tämä tapahtui ilman yksilöllistä tilannearviota. ...Ymmärsin, ettei heistä ole apua minun työllistymiseeni ja en halunnut vaihtaa ammatti vaan ylläpitää minun oman alan jos on mahdollista. Mutta se ei onnistunut näin.

Kansainvälistä uraa luonut Maya oli pettynyt saatuaan ohjeen hakeutua siivousalalle. Jemina oli jäänyt työttömäksi IT-alan työtehtävistä. Vaikka hän oli tässä vaiheessa asunut, opiskellut ja työskennellyt Suomessa pitkään, työttömäksi jäätyään hän koki joutuvansa uudelleen "maahanmuuttajakategoriaan". Jeminan hämmästykseksi TE-palvelujen vastuuvirkailija kannusti häntä uudelleenkouluttautumaan hoiva-alalle: Tuntu että se jako kaikille meikä näköisille samat neuvot. Ikään kun se oli jotain neuvottu että ton näkösii porukka tätä, ton näkösii porukkaa sitä... ja sit toisenlaiset porukka tota. Haastateltava tuli siis kohdelluksi maahanmuuttotaustan kautta asuttuaan, opiskeltuaan ja työskenneltyään jo pitkään Suomessa.

Syntyy kuva, ettei haastateltavien yksilöllisiin tilanteisiin ollut ehditty keskittyä. Tämä on voinut johtua henkilöstöresurssien vähäisyydestä tai kiireestä. Stereotyyppinen toiminta ja syrjivä kohtelu työelämään ohjaamisen vaiheessa on usein tahatonta. Tarkoitus voi olla hyvä: auttaa työtöntä työnhakijaa löytämään töitä työvoimapula-alalta. Lähihoitajan työ on arvokasta ja tärkeää, mutta ongelmallista on, jos työnhakijoita ohjataan alalle siksi, että heidän ajatellaan soveltuvan hoivatyöhön maahanmuuttaneina naisina, uskontonsa tai kulttuurinsa vuoksi (Kurki 2018; myös Krivonos 2021). Muutama haastateltava nosti esiin vastakkaisen näkökulman ja korosti olleensa valmis tekemään myös koulutusta vastaamatonta työtä välttyäkseen työttömyydeltä.

\section{Esteitä ennen haastattelukutsua}

Rekrytointiprosessissa hakemuspaperit, työhaastattelu(t) ja suositukset muodostavat kokonaisuuden, jonka perusteella työnantaja valitsee tehtävään mielestään sopivimman henkilön. Työhaastatteluun kutsumisen vaiheessa koulutus ja työkokemus ovat yleensä ratkaisevimpia tekijöitä (Huilaja 2019). Haastateltavat kertoivat, että huolimatta aktiivisesta työpaikkojen hakemisesta kutsuja haastatteluihin 
ei usein tullut. Se, ettei hakemuksiin saanut edes vastauksia, aiheutti hämmennystä ja pettymystä (myös Alho 2020; Liversage 2009). Rebecca muisteli lähettäneensä yhden vuoden aikana 250-300 hakemusta ja saaneensa kutsun työhaastatteluun neljä kertaa. Layla kertoi lähettäneensä noin 200 hakemusta puolen vuoden aikana saamatta kutsuja haastatteluihin.

Haastateltavilla on yhtä poikkeusta lukuun ottamatta ulkomaalaiselta kuulostava sukunimi. Aiemmat tutkimukset osoittavat, että työnhakijan nimellä on väliä rekrytointiprosessissa (Ahmad 2019; Booth ym. 2012; Larja ym. 2012; Lulle \& Balode 2014). Nimen lisäksi aukot ansioluettelossa voivat sulkea oven jo rekrytoinnin alkuvaiheessa (Huilaja 2019, 55). Aisha, joka on suorittanut opintonsa Suomessa ja puhuu suomea erinomaisesti, kuvaa kokemuksiaan:

Kun sanot sun nimen, paikka on jo täytetty ...jos mä pääsen työhaastatteluun, niin kyl mä saan sen duunipaikan, että harvassa kohtaa on jäänyt paikka saamatta haastatteluun päästyäni, et tosi usein ne esteet on niinku jo ennen kun sä pääset haastatteluun, kun sulta kysytään äidinkieltä ja syntymämaata ja... muuta tämmöistä.

Aishalta oli tiedusteltu myös, mistä hän tai hänen vanhempansa "ovat lähtöisin", jo siinä vaiheessa, kun hän otti yhteyttä työnantajaan. Seikkula ja Hortelano (2021, 160) korostavat, että myös viattomilta vaikuttavat ja uteliaisuudesta esitetyt taustaa koskevat kysymykset voivat olla toistuessaan raskaita, kun yksilö nähdään arkisissa kohtaamisissa jatkuvasti ei-paikallisena. Valkoinen etuoikeus tarkoittaa, etteivät kysymysten esittäjät tule kokemaan kysymysten vaikutuksia eli sitä, miten ne sijoittavat kohteensa yhteiskunnan ulkopuolelle.

\section{Työhaastatteluja muodon vuoksi}

Rekrytointiprosessissa kohtaamisia työnantajan ja työnhakijan välillä voi olla yksi tai useampia. Rekrytointi on valikoitumisen prosessi, jossa valinnan valtatasapaino vaihtelee eri vaiheissa ja tilanteissa (Huilaja 2019, 54-55). Vaikka yritysten rekrytointikäytännöt olisivat vakioidut, voi itse tilanteissa olla vaihtelua läsnäolijoiden, heidän taustojensa, tunteidensa tai mieltymystensä mukaan. Työhaastattelu on vuorovaikutustilanne, jossa menestymiseen voivat vaikuttaa esimerkiksi sukupuoli, pukeutuminen tai etninen tausta. 
Haastateltavista Rebecca, Janet ja Aisha kuvasivat kokemuksiaan työhaastatteluista. Rebecca sai kutsun ryhmähaastatteluun haettuaan asiantuntijatehtävää valtion virastosta. Hän kertoi olleensa haastattelutilanteessa ainut, jonka äidinkieli ei ollut suomi. Rebeccan mukaan haastattelija oli puhunut hänen "ohitseen", mikä oli aiheuttanut hänelle kokemuksen, ettei hän tullut kohdatuksi tilanteessa muiden hakijoiden tavoin. Janet kertoi hakeneensa asiantuntijatehtävää korkeakoulusta. Työkielen kerrottiin olevan englanti. Haastattelussa Janetin suomen kieltä kuitenkin testattiin, ja: Tottakai se suomalainen sai sen työpaikan koska hän osasi suomea. Myös Aisha koki tulleensa kutsutuksi haastatteluun muodon vuoksi. Hän muisteli työhaastattelutilannetta valtion virastossa, jossa työnantajan edustaja oli kysellyt häneltä "yhteisön" kuulumisia: Tosi outo se tilanne... haluttiinko tilastoihin, että on haastateltu mustaa musliminaista tehtävään. Aisha kertoi myös kohdanneensa ylikorostuneita suomen kielen taitovaatimuksia hakiessaan työpaikkaa siivousalan firmasta. Afrikan mantereelta Suomeen muuttaneelle Jeminalle tarjottiin tehtävää IT-alan yrityksessä. Kun hän matkusti pääkaupunkiseudulle allekirjoittamaan työsopimusta, työnantajan edustaja ilmoitti, ettei työssä aloitus onnistukaan Jeminan puuttuvan ruotsin kielen taidon vuoksi. Jemina muisteli tilannetta: Hänen esimies oli sitä mieltä, että kun minä en osaa ruotsia... vaikka tämä oli tiedossa koko prosessin aikana... sit se sano mulle off the record, kun sinä olet tumma. Työnantaja yritti vedota puuttuvaan ruotsin kielen taitoon, vaikka kyseistä kieltä ei työtehtävässä vaadittu. Huolimatta rasismista ja rodullistamisesta Jemina ei tehnyt valitusta vaan jatkoi työnhakua.

Anna ja Aisha käyttävät päähuivia eli hijabia. Huivi oli noussut teemaksi myös Aishan työhaastattelussa:

Sitte ne kysy tosi paljon siitä, että mun suhtautumisesta jos asiakkaat ois hankalia eli niillä oli huoli ja oletus siitä, että jos ne pistää mun näköisen ihmisen tiskiin, sillon vois olla että joudun kohtaamaan aika paljon asiakkailta, että onko mulla valmiuksia ja osaanko esimiehelle sanoa ja niinku näin... mä sain ainakin sen kuvan, että siellä saattoi olla taustalla ihan aito huoli siitä, että... toisaalta ne halusi tarjota mulle sen mahdollisuuden, koska mä olin se mitä ne haki, kaikkien testien perusteella.

Aisha pyrki vastaamaan holhoaviin ja kiusallisiin kysymyksiin asiallisesti ja ymmärtämään myös työnantajan näkökulmaa. Samanaikaisesti hänellä oli "kaksoistietoisuus" ilmiöstä, jossa rasismin kohteeksi joutuva on tietoinen omien koke- 
mustensa lisäksi myös siitä, miten tulee nähdyksi rasististen käsitysten läpi (Seikkula \& Hortelano 2021).

\section{Syrjintään reagointi ja strategiat}

Kuvasin edellä työnhakuprosessin eri vaiheisiin liittyviä syrjinnän ja rasismin kokemuksia. Koulutus ja monipuolinen työkokemus tai edes erinomainen suomen kielen taito eivät suojanneet korkeasti koulutettuja maahanmuuttaneita syrjinnältä. Tässä alaluvussa kerron, miten haastateltavat reagoivat ja vastasivat kohtaamaansa syrjintään. Reagointitavat ja strategiat syrjintää ja rasismia kohdattaessa vaihtelivat yksilöllisesti, ja niitä myös vaihdeltiin ja yhdisteltiin tilannekohtaisesti (myös Verwiebe ym. 2016).

Suorista strategioista kertoi esimerkiksi Rebecca. Saatuaan ohjeen kouluttautua uudelleen lähihoitajaksi Rebecca kertoi kieltäytyneensä noudattamasta ohjetta ja alkaneensa etsiä itsenäisesti tietoa aiemmin hankkimansa sosiaalialan tutkinnon rinnastamisesta. Hän hakeutui myös kolmannen sektorin toiminnan pariin ja osallistui mentorointiohjelmaan.

Suoraa reagointitapaa yleisempi oli välttelevä, ei-hyökkäävä strategia (Noh ym. 1999; Swim ym. 1998). Saatuaan ohjeen kouluttautua lähihoitajaksi Jemina kertoi kysyneensä TE-palvelujen vastuuvirkailijaltaan, kuinka monesta potilaasta halutaan päästä eroon, kun juuri hänet halutaan ohjata hoiva-alalle. Tulkitsen Jeminan toistuvasti käyttämän strategian - ironian - toimineen pyrkimyksenä selvitä tilanteesta kasvojaan menettämättä (myös Verwiebe 2016).

Usea haastateltava kuvasi psyykkisiä reaktioita, kuten tunnereaktiota ja hallintareaktioita. Nämä tarkoittivat turhautumista, vihan tunteita, ahdistusta, masennusta ja muita oireita. Hallintareaktioihin lukeutuvista strategioista torjunta ja syiden etsiminen itsen ulkopuolelta näkyivät esimerkiksi Olgan kertomuksessa. Olga totesi ensin, ettei ole koskaan kokenut työnhakuvaiheen syrjintää Suomessa. Hetken emmittyään hän muutti kertomustaan, mutta painotti tiukasti, että syy tilanteisiin löytyy yleensä työntekijöiden erilaisista toimintatavoista, ei tietoisesta syrjinnästä maahanmuuttanutta työnhakijaa kohtaan. Aisha kertoi tehneensä aina liikaa töitä oman hyvinvointinsa kustannuksella. Kova työmoraali oli hänen mukaansa kotoa opittua: 
Mutsi aina sanoo, että jos sä oot jossain, ni homma kunnolla kotiin tai älä mene... et ihan turha mennä tekeen keskinkertaista... ja sit se tietty paine siitä, että mustana musliminaisena jos sä teet hommat samaan tahtiin kun mitä valkoinen nainen esimerkiksi tekee niin se ryhmä johon sä kuulut kärsii siitä.

Aisha korosti, että mikäli hän ei ole virheetön työntekijä ja suoriudu työtehtävistään erinomaisesti, sillä voi olla kielteisiä seurauksia myös muille maahanmuuttaneille (ks. myös Ahmad 2010, 158; Könönen 2011). Ylisuorittaminen onkin yksi rasismia kohtaavan selviytymisstrategioista. Linjassa aiempien tutkimusten kanssa (esim. Aalto ym. 2010) tämänkään aineiston haastateltavat eivät tehneet valitusta syrjivästä kohtelusta. Tähän voi olla useita syitä. Ensinnäkin syrjinnän ja rasismin kohteeksi joutuminen voi aiheuttaa häpeää ja lamaantumista. Toiseksi yksilö pyrkii säilyttämään arvokkuutensa ja hallinnan tunteensa kohdatessaan epäoikeudenmukaista kohtelua. Valituksen voidaan ajatella olevan hyödytön, johtavan oman aseman vaikeutumiseen työnhakijana tai estävän oleskeluluvan saamisen (Jasinskaja-Lahti ym. 2002, 46-47). Haastateltavien kertomuksissa korostuvat myös yksilölliset ominaisuudet, kuten joustavuus, periksiantamattomuus ja "sisu". Deborah painotti sisäistä voimaa: Olen nähnyt ja olen tuntenut, kuinka paljon ihmisellä voivat olla vahva... ja samalla joustavaa. Ja kuinka optimismi ei anna periksi kovimmissa hetkissä.

\section{Johtopäätökset ja pohdintaa}

Tutkimus tuo esiin korkeasti koulutettujen maahanmuuttaneiden naisten työnhakuprosessin sukupuolittuneena ilmiönä ja antaa uutta tietoa syrjintään ja rasismiin reagoimisen strategioista sekä syrjinnän moniulotteisista seurauksista. Työnhaku muodostui haastateltaville odotettua haastavammaksi ja pidemmäksi prosessiksi koulutuksesta, työkokemuksesta sekä aktiivisesta sosiaalisen ja instrumentaalisen tuen hakemisesta huolimatta. Pitkittyvä työttömyys heikensi hyvinvointia ja aiheutti raskasta tunnekuormaa. Työnhakuprosessiin liittyvien tunteiden roolista tarvitaankin lisää tutkimusta (esim. Aure 2013). On myös tärkeää nähdä korkeasti koulutettujen maahanmuuttaneiden tukeminen kokonaisvaltaisena prosessina, jossa otetaan huomioon muitakin kuin suoraan työllistämiseen liittyviä tekijöitä. Perheellisillä puolison ja lasten sopeutuminen uuteen yhteiskuntaan vaikuttaa viihtyvyyteen sekä päätökseen pysyä Suomessa (myös Lulle \& Balode 2014). 
Haastateltavien kertomuksista nousivat esiin työnhakuvaiheessa koetut mikroaggressiot, syrjintä, rasismi ja rodullistaminen. Vaikka tutkimukseen osallistuneet ovat muuttaneet Suomeen eri vuosikymmenillä, heidän kokemuksissaan on yhtäläisyyksiä. Syrjivä kohtelu ilmeni yleisinä ennakkoluuloina ja suomen kielen taitotasoon kohdistuneina ylikorostuneina vaatimuksina. Sellaistenkin työnhakijoiden suomen kielen taidon puutteellisuuteen vedottiin, joiden suomen kieli oli lähes äidinkielen tasoa. Rasismi ja rodullistaminen kohdistuivat työnhakijoiden taustaan, vaatetukseen tai ihonväriin. Eniten syrjinnästä ja rasismista raportoivat Afrikan mantereelta muuttaneet.

Reaktiot ja strategiat syrjintää ja rasismia kohdattaessa vaihtelivat yksilöllisesti, ja niitä vaihdeltiin tilannekohtaisesti. Haastateltavat eivät juurikaan kuvanneet syrjintään puuttumista tai tilanteiden käsittelyä. Käsittely on kuitenkin tärkeää, koska se voi auttaa yksilöä pitämään yllä käsitystä itsestään aktiivisena toimijana (Jasinskaja-Lahti ym. 2007). Lisäksi syrjintään reagoimisen strategia vaikuttaa tilanteesta selviytymiseen. Suora reaktio syrjintään voi heikentää kokemuksen kielteistä vaikutusta ja uhriksi joutumisen tunnetta. Välttelevät reaktiot voivat puolestaan lisätä stressiä, mikäli syrjintätilanne jää käsittelemättä (Jasinskaja-Lahti ym. 2002). Syrjivällä kohtelulla on vakavia seurauksia yksilöiden hyvinvoinnille, työurien käynnistymiselle ja tuottavuudelle (myös Pietiläinen ym. 2018; PolancoRoman ym. 2016; Rask ym. 2018). Erityisesti moniperusteisen syrjinnän muodoista ja seurauksista tarvitaan lisää tutkimustietoa (Oikeusministeriö 2019, 3, 7). Yhdenvertaisessa yhteiskunnassa eri väestöryhmien tulisi olla edustettuina työelämässä (Rask ym. 2018, 2). Tämä koskee myös julkishallinnon organisaatioita, jotka ovat merkittäviä yhteiskunnallisen vallan käyttäjiä (Rask ym. 2021). Korkeasti koulutettujen maahanmuuttaneiden naisten työllistymistä hidastavista rakenteellisista esteistä sekä urakehityksestä tarvitaankin edellä mainituista syistä lisää tutkimusta (Irastorza \& Bevelander 2021; Mustosmäki ym. 2021; Nardon ym. 2021).

Aineisto on monipuolinen, mutta tutkimuksen tuloksia ei voi yleistää koskemaan kaikkia korkeasti koulutettuja maahanmuuttaneita naisia Suomessa. On myös huomioitava, että tutkimuksen aihe on sensitiivinen. Etenkin mahdollisista syrjinnän ja rasismin kokemuksista on voitu haluta puhua valikoiden tai vaieta (Pietiläinen ym. 2018, 60). Aineisto on kerätty pääosin vuosina 2016-2018 eli ennen koronapandemiaa. Koronan vaikutuksista korkeasti koulutettujen maahanmuuttaneiden naisten työllistymiseen tarvitaan lisää tietoa myös Suomessa (ks. Nardon ym. 2021). 


\section{Työelämän kehittämisehdotuksia}

Monimuotoinen ja syrjimätön työelämä edistäisi maahanmuuttaneiden työllistymistä sekä lisäisi Suomen houkuttelevuutta kansainvälisten opiskelijoiden ja työvoiman kohdemaana. Huomiota tulisi kiinnittää etenkin puolison roolissa Suomeen muuttaviin. Suurin osa naisista - myös korkeasti koulutetuista - muuttaa Suomeen perhesyistä, jolloin heillä ei useinkaan ole työpaikkaa valmiina. Koska naisen rooli hoivavastuunkantajana voi korostua maahanmuuttoprosessissa (Fossland 2013, 279), tulisi hoivavelvollisuuksien vaikutusta työllistymiseen tutkia laajemmin (esim. Terävä ym. 2011). Tukea ja mahdollisuuksia rakentaa ammatillisia verkostoja tarvitaan heti maahantulon jälkeen.

Koulutukseen ja työelämään ohjaamisen vaiheessa ilmenevää rakenteellista syrjintää voidaan ehkäistä takaamalla riittävät ohjaustyön resurssit eri sektoreilla toimiville asiantuntijoille sekä ylläpitämällä henkilöstön yhdenvertaisuusosaamista (myös Steel \& Jyrkinen 2017). Nykyiseen hallitusohjelmaan on kirjattu tavoite lisätä työnantajien rekrytointi- ja monimuotoisuusosaamista. Rekrytointimenetelmien uudistamisesta on saatu alustavasti myönteisiä tuloksia. Monimuotoisuuslausekkeella työnantaja voi ilmaista myönteistä suhtautumistaan monimuotoisuuden edistämiseen ja kannustaa vähemmistöihin kuuluvia hakemaan avoinna oleviin tehtäviin. Anonyymi rekrytointi on yksi keino, jolla pyritään lisäämään yhdenvertaisuutta. Toistaiseksi sen käytöstä saadut tutkimustulokset ovat kuitenkin ristiriitaisia (Behaghel ym. 2015; Kanninen \& Virkola 2021). Menetelmä ei myöskään automaattisesti ehkäise syrjintää rekrytointiprosessin myöhemmissä vaiheissa. Tekoälyn hyödyntäminen rekrytointipäätöksenteon tukena voi parhaassa tapauksessa tuoda valintatilanteisiin läpinäkyvyyttä (Kanninen \& Virkola 2021, 21), mutta lisää tutkimustietoa tarvitaan teknologian hyödyntämisen kielteisistä seurauksista, kuten olemassa olevien vinoumien vahvistamisesta (ks. Kleinberg ym. 2018).

Maahanmuuttaneiden työllistymisen haasteita selitetään usein julkisuudessa yksilöiden puutteellisilla ominaisuuksilla (Huilaja 2019). Jos vastuu työllistymisestä siirretään täysin yksilön ominaisuuksien ja aktiivisuuden varaan, unohtuu keskustelu ympäröivän yhteiskunnan rakenteista ja niiden muuttumisen tarpeista (Kurki 2018). Rekrytointi on keskeinen työelämän tapahtuma, joka eri tavoin toteutuvina valintoina pitää yllä sekä vahvistaa sosiaalista järjestystä ja siihen kytkeytyviä valtasuhteita. Työnantajien toiminnasta rekrytoinnissa tarvitaan lisää tutkimusta 
- kuten siitä, miten työnhakuprosessi toimii käytännön tilanteena (Huilaja 2019) ja miten yhdenvertaisuuslainsäädäntöä rikkovat mekanismit edelleen käytännössä mahdollistuvat. Kuten tämäkin tutkimus osoittaa, syrjinnän kieltävä lainsäädäntö ei ole kyennyt poistamaan korkeasti koulutettujen maahanmuuttaneiden kohtaamaa työnhakuvaiheen syrjintää ja rasismia. Ne eivät vähene ilman perusteellista asennemuutosta ja konkreettisia toimenpiteitä (myös Ahmad 2019; Kanninen \& Virkola 2021). Tähän osallistavaan ja ratkaisukeskeiseen dialogiin ja toimintaan tarvitaan mukaan niin kotoutumispalveluja tuottavia tahoja, työnantajia kuin maahanmuuttaneita työnhakijoitakin.

\section{Kirjoittaja}

\section{Heidi Lehtovaara}

FM, väitöskirjatutkija, Tampereen yliopisto

sähköposti: heidi.lehtovaara@tuni.fi

twitter: @heidilehtovaara

\section{Kirjallisuus}

Aalto, M., Larja L. \& Liebkind K. (2010) Syrjintä työhönottotilanteissa - tutkimuskatsaus. Työ- ja elinkeinoministeriön julkaisuja. Työ ja yrittäjyys 16/2010. https://docplayer.fi/14203742-Syrjinta-tyohonottotilanteissa-tutkimuskatsaus.html (luettu 20.9.2021)

Ahmad, A. (2010) "Voisin tietty palkata heitä, mutta...": Työmarkkinoiden sosiokulttuurinen sidonnaisuus'. Teoksessa S. Wrede \& C. Nordberg (toim.) Vieraita työssä: Työelämän etnistyvä eriarvoisuus. Helsinki: Palmenia, 72-92. Ahmad, A. (2019) Kokeellinen tutkimus etniseen alkuperään perustuvasta syrjinnästä suomalaisilla työmarkkinoilla. Teoksessa V. Kazi, A. AlitolppaNiitamo \& A. Kaihovaara (toim.) Kotoutumisen kokonaiskatsaus 2019: Tutkimusartikkeleita kotoutumisesta. TEM oppaat ja muut julkaisut 2019:10. Helsinki: Työ- ja elinkeinoministeriö, 15-27.

Alho, R. (2020) 'You need to know someone who knows someone': International students' job-search experiences. Nordic Journal of Working Life Studies 10 (2), 3-22. https://doi.org/10.18291/njwls.v10i2.120817 
Aure, M. (2013) The emotional cost of employment-related mobility. Norwegian Journal of Geography 67 (5), 284-294. https://doi.org/10.1080/00291951.2013. 847855

Bastia, T. (2014) Intersectionality, migration and development. Progress in Development Studies 14 (3), 237-248.

Behaghel, L., Crépon, B. \& Le Barbanchon, T. (2015) Unintended effects of anonymous résumés. American Economic Journal: Applied Economics 7 (3), 1-27. https://doi.org/10.1257/app.20140185

Bertrand, M. \& Mullainathan, S. (2004) Are Emily and Greg more employable than Lakisha and Jamal? A field experiment on labor market discrimination. American Economic Review 94 (4), 991-1013. https://doi.org/10.3386/w9873

Booth, A., Leigh, A. \& Varganova, E. (2012) Does ethnic discrimination vary across minority groups? Evidence from a field experiment. Oxford Bulletin of Economics and Statistics 74 (4), 547-573. https://doi.org/10.1111/j.1468-0084.2011.00664.x

Busk, H., Jauhiainen, S., Kekäläinen, A., Nivalainen, S. \& Tähtinen, T. (2016) Maahanmuuttajat työmarkkinoilla - tutkimus eri vuosina Suomeen muuttaneiden työurista. Eläketurvakeskuksen tutkimuksia 06/2016. Helsinki: Eläketurvakeskus. https://www.kela.fi/documents/10180/1169652/160914+Maahanmuuttajat_tyomarkkinoilla.pdf (luettu 20.9.2021)

Butler, J. (2006) Hankala sukupuoli. Helsinki: Gaudeamus.

Crenshaw, K. (1989) Demarginalizing the intersection of race and sex: A black feminist critique of antidiscrimination doctrine, feminist theory and antiracist politics. University of Chicago Legal Forum 1/1989, 139-167.

Davydova, 0. (2012) Venäjän lännestä Suomen itään: Sukupuolittunut maahanmuutto ja haurastuneet työmarkkinat. Teoksessa S. Keskinen, J. Vuori \& A. Hirsiaho (toim.) Monikulttuurisuuden sukupuoli: Kansalaisuus ja erot hyvinvointiyhteiskunnassa. Tampere: Tampere University Press, 72-100.

Essed, P. (1991) Understanding everyday racism: An interdisciplinary study. Newbury Park: Sage.

Fossland, T. (2013) Crossing borders - getting work: Skilled migrants' gendered labour market participation in Norway. Norwegian Journal of Geography 67 (5), 276-283. https://doi.org/10.1080/00291951.2013.847854 
FRA (2017) EU-MIDIS II: Muslims - Selected findings. European Union Agency for Fundamental Rights. https://fra.europa.eu/en/publication/2017/secondeuropean-union-minorities-and-discrimination-survey-eu-midis-iimuslims (luettu 27.9.2021).

Grönlund, A. \& Nordlund, M. (2021) A maternal wall for refugees? Gender and labor market establishment in Sweden. https://doi.org/10.18291/njwls.128041

Haapakorpi, A. (2007) Työvoimapula ja etnospesifit työmarkkinat - miten edistää korkeakoulutettujen maahanmuuttajien ammatillista sijoittumista? Työelämän tutkimus 5 (3), 213-226.

Habti, D. \& Koikkalainen, S. (2013) International highly skilled migration: The case of Finland: An introduction. Journal of Finnish Studies 17 (1\&2), 3-17.

Huilaja, H. (2019) Rekrytoinnin sosiaalinen järjestys: Tutkimus työhön sopivuuden neuvottelukontekstista. Acta electronica Universitatis Lapponiensis 260. Rovaniemi: Lapin yliopisto. http://urn.fi/ URN:ISBN:978-952-337-148-4

Irastorza, N. \& Bevelander, P. (2021) Skilled migrants in the Swedish labour market: An analysis of employment, income and occupational status. Sustainability 13 (6): article 3428. https://doi.org/10.3390/su13063428

Jasinskaja-Lahti, I., Liebkind, K. \& Vesala, T. (2002) Rasismi ja syrjintä Suomessa: maahanmuuttajien kokemuksia. Helsinki: Gaudeamus.

Jasinskaja-Lahti, I., Liebkind, K. \& Perhoniemi, R. (2007) Perceived ethnic discrimination at work and well-being of immigrants in Finland: The moderating role of employment status and work-spesific group-level control beliefs. International Journal of Intercultural Relations 31 (2), 223-242. https://doi.org/10.1016/j.ijintrel.2006.02.003

Kanninen, O. \& Virkola, T. (2021) Rekrytointisyrjintä ja sen vastaiset keinot. Valtioneuvoston selvitys- ja tutkimustoiminnan julkaisusarja 2021:27. Helsinki: Valtioneuvoston kanslia.

Kazi, V., Alitolppa-Niitamo, A. \& Kaihovaara, A. (2019) Kotoutumisen kokonaiskatsaus 2019: Tutkimusartikkeleita kotoutumisesta. TEM oppaat ja muut julkaisut 2019:10. Helsinki: Työ- ja elinkeinoministeriö.

Kleinberg, J., Ludwig, J., Mullainathan, S. \& Sunstein, C. R. (2018) Discrimination in the age of algorithms. Journal of Legal Analysis 10, 113-174. https://doi.org/10.1093/jla/lazo01 
Korkiasaari, J. \& Söderling, I. (2007) Muuttoliike. Teoksessa S. Koskinen, T. Martelin, I.-L. Notkola, V. Notkola, K. Pitkänen, M. Jalovaara, E. Mäenpää, A. Ruokolainen, M. Ryynänen \& I. Söderling (toim.) Suomen väestö, Helsinki: Gaudeamus, 244-245.

Koskela, K. (2020) Negotiating the "migrant elite": Boundary making and social identities among skilled migrants in Finland. University of Helsinki, Publications of the Faculty of Social Sciences 163.

Krivonos, D. (2021) Valkoisuus, luokka ja rodullinen eriarvoisuus. Teoksessa Rasismi, valta ja vastarinta: Rodullistaminen, valkoisuus ja koloniaalisuus Suomessa. Helsinki: Gaudeamus, 164-184.

Kurki, T. (2018) Immigrant-ness as (mis)fortune? Immigrantisation through integration policies and practices in education. University of Helsinki, Faculty of Educational Sciences, Helsinki Studies in Education 40.

Kurronen, S. (2021) Maahanmuuttajanaisten loukku. EVA arvio 9.2.2021. https:// www.eva.fi/wp-content/uploads/2021/02/eva-arvio-030.pdf (luettu 25.9.2021)

Kuusio, H., Seppänen, A., Jokela, S., Somersalo, L. \& Lilja, E. (toim.) (2020) Ulkomaalaistaustaisten terveys ja hyvinvointi. FinMonik-tutkimus 2018-2019. Terveyden ja hyvinvoinnin laitoksen julkaisuja, Raportti 1/2020. Helsinki.

Kyhä, H. (2011) Koulutetut maahanmuuttajat työmarkkinoilla: Tutkimus korkeakoulututkinnon suorittaneiden maahanmuuttajien työllistymisestä ja työurien alusta Suomessa. Turun yliopiston julkaisuja C 321. Turku.

Könönen, J. (2011) Palvelualan työnantajat ja joustavat ulkomaalaiset työntekijät: Maahanmuuttohallinnon merkitys prekaarin työvoiman tuottamisessa. Janus 19 (1), 52-67.

Könönen, J. \& Himanen, M. (2019) Maahanmuuton sääntelyn ja etnisen syrjinnän yhteydet maahanmuuttajien työmarkkina-asemaan. Teoksessa V. Kazi, A. Alitolppa-Niitamo \& A. Kaihovaara (toim.) Kotoutumisen kokonaiskatsaus 2019: Tutkimusartikkeleita kotoutumisesta. TEM oppaat ja muut julkaisut 2019:10. Helsinki: Työ- ja elinkeinoministeriö, 54-65.

Laki naisten ja miesten välisestä tasa-arvosta 8.8.1986/609. https://finlex.fi/fi/ laki/ajantasa/1986/19860609

Larja, L. (2019) Maahanmuuttajanaiset työmarkkinoilla ja työmarkkinoiden ulkopuolella. Teoksessa V. Kazi, A. Alitolppa-Niitamo \& A. Kaihovaara (toim.) Kotoutumisen kokonaiskatsaus 2019: Tutkimusartikkeleita kotoutumisesta. 
TEM oppaat ja muut julkaisut 2019:10. Helsinki: Työ- ja elinkeinoministeriö, $28-42$.

Larja, L. (2021) Maahanmuuttaneet naiset työmarkkinoilla. Seminaariesitelmä 12.11.2021. Työ- ja elinkeinoministeriö.

Larja, L. \& Sutela, H. (2015) Työllisyys: Ulkomaalaistaustaisten miesten työllisyysaste lähes samalla tasolla kuin suomalaistaustaisella - naisilla enemmän vaikeuksia työllistyä. Teoksessa T. Nieminen, H. Sutela \& U. Hannula (toim.) Ulkomaista syntyperää olevien työ ja hyvinvointi Suomessa 2014. Helsinki: Tilastokeskus, 71-83.

Larja, L., Warius, J., Sundbäck, L., Liebkind, K., Kandolin, I. \& Jasinskaja-Lahti, I. (2012) Discrimination in the Finnish labour market - An overview and a field experiment on recruitment. Työ- ja elinkeinoministeriö. Työ ja yrittäjyys $16 / 2012$.

Lazarus, R. S. \& Folkman, S. (1984) Stress, appraisal, and coping. New York: Springer.

Lehtovaara, H. \& Jyrkinen, M. (2021) Skilled migrant women's experiences of the job search process. Nordic Journal of Working Life Studies 11 (57), 11-30. https://tidsskrift.dk/njwls/article/view/128588/174608

Lehtovaara, H. \& Säppi, J. (2021) Erillisiä työllistämispalveluja maahan muuttaneille naisille - yhdenvertaisuutta vai toiseuttamista? Sukupuolentutkimus - Genusforskning 34 (3), 50-54.

Liebkind, K., Larja, L. \& Brylka, A. (2016) Ethnic and gender discrimination in recruitment: Experimental evidence from Finland. Journal of Social and Political Psychology 4 (1), 403-426. https://doi.org/10.5964/jspp.v4i1.433

Liversage, A. (2009) Vital conjunctures, shifting horizons: High-skilled female immigrants looking for work. Work, Employment and Society 23 (1), 120-141. https://doi.org/10.1177\%2F0950017008099781

Lulle, A. \& Balode, M. (2014) Marriage migration and skills: Narratives of Latvian women in Finland. Journal of Finnish Studies 17 (1), 67-91.

Maury, 0. (2020) Punctuated temporalities: Temporal borders in studentmigrants' everyday lives. Current Sociology. https://doi. org/10.1177/0011392120936315

McCall, L. (2005) The complexity of intersectionality. Journal of Women in Culture and Society 30 (3), 1771-1800. https://doi.org/10.1086/426800 
Miles, M. B. \& Huberman, A. M. (1994) Qualitative data analysis: An expanded sourcebook. (2. ed.) Thousand Oaks: Sage.

Mustosmäki, A., Reisel, L., Sihto, T. \& Teigen, M. (2021) Gendered labor market (dis)advantages in Nordic welfare States: Introduction to the theme of the special issue. Nordic Journal of Working Life Studies 11 (S7), 1-9. https://doi.org/10.18291/njwls.129190

Nardon, L., Hari, A., Zhang, H., Hoselton, L. P. S. \& Kuzhabekova, A. (2021) Skilled immigrant women's career trajectories during the COVID-19 pandemic in Canada. Equality, Diversity and Inclusion. https://doi.org/10.1108/EDI-092020-0255

Noh, S., Beiser, M., Kaspar, V., Hou, F. \& Rummens, J. (1999) Perceived racial discrimination, depression and coping: A study of Southeast Asian refugees in Canada. Journal of Health and Social Behavior 40 (3), 193-207. https://doi.org/10.2307/2676348

OECD (2018) Economic Survey of Finland. http://www.oecd.org/eco/surveys/ economic-survey-finland.htm (luettu 15.11.2021)

Oikeusministeriö (2019) Moniperusteinen syrjintä olisi tunnistettava paremmin. Policy Brief 2, Syrjintä Suomessa. Ajankohtaista tietoa syrjinnästä ja yhdenvertaisuudesta. https://yhdenvertaisuus.fi/documents/5232670/5376058/ Policy+Brief +moniperusteinen+syrjint\%C3\%A4 (luettu 29.9.2021).

Oikeusministeriö (2021) Yhdenvertainen Suomi: Valtioneuvoston toimintaohjelma rasismin torjumiseksi ja hyvien väestösuhteiden edistämiseksi. Oikeusministeriön julkaisuja 2021:34. Helsinki. http://urn.fi/ URN:ISBN:978-952-259-808-0

Pietiläinen, M., Viitasalo, N., Nätti, J., Ojala, S. \& Korvajärvi, P. (2016) Ikä- ja sukupuolisyrjintä työssä. Talous \& Yhteiskunta 44 (4), 42-47.

Pietiläinen, M., Viitasalo, N., Lipiäinen, L., Ojala, S., Leinonen, M., OtonkorpiLehtoranta, K., Jokinen, E., Korvajärvi, P. \& Nätti, J. (2018) Työssä koettu syrjintä ja myöhempi työura. Loppuraportti. Työsuojelurahaston tutkimushanke 2015-2017. Tampereen yliopisto. http://www.urn.fi/ URN:ISBN:978-952-03-0662-5

Polanco-Roman, L., Danies, A. \& Anglin, D. M. (2016) Racial discrimination as race-based trauma, coping strategies, and dissociative symptoms among 
emerging adults. Psychological Trauma: Theory, Research, Practice, and Policy 8 (5), 609-617. https://doi.org/10.1037/tra0000125

Rask, S., Elo, I., Koskinen, S., Lilja, E., Koponen, P. \& Castaneda, A. (2018) The association between discrimination and health: Findings on Russian, Somali and Kurdish origin populations in Finland. European Journal of Public Health 28 (5), 898-903. https://doi.org/10.1093/eurpub/cky100

Rask, S., Nykänen, S. \& Teräsaho, M. (2021) Monimuotoisuutta edistävä rekrytointi: Moninaisesti parempi -hankkeen rekrytointikokeilun tuloksia. Työpaperi 10/2021. Helsinki: Terveyden ja hyvinvoinnin laitos.

Seikkula, M. \& Hortelano, P. (2021) Arjen rasismi ja rasisminvastaisuus arjessa. Teoksessa S. Keskinen, M. Seikkula \& F. Mkwesha (toim.) Rasismi, valta ja vastarinta: Rodullistaminen, valkoisuus ja koloniaalisuus Suomessa. Helsinki: Gaudeamus, 147-161.

Seikkula, M. \& Keskinen, S. (2021) Johdanto: Muuntautuva rasismi ja moninainen antirasismi. Teoksessa S. Keskinen, M. Seikkula \& F. Mkwesha (toim.) Rasismi, valta ja vastarinta. Rodullistaminen, valkoisuus ja koloniaalisuus Suomessa. Helsinki: Gaudeamus, 9-21.

Steel, T. \& Jyrkinen, M. (2017) Searching for employment: Highly educated immigrant women and combined capabilities. Research on Finnish Society $10(1), 35-42$.

Steel, T. \& Tuori, A. (2016) "Olenko minä niin eksoottinen?" Pakolaistaustaisten naisten työelämään liittyvä identiteettityö. Elore 23 (2). https://doi.org/10.30666/elore.79258

Suomen perustuslaki 11.6.1999/731. https://www.finlex.fi/fi/laki/ ajantasa/1999/19990731

Swim, J. K., Cohen, L. L. \& Hyers, L. L. (1998) Experiencing everyday prejudice and discrimination. Teoksessa J. K. Swim \& C. Stangor (toim.) Prejudice: The target's perspective. San Diego, CA: Academic Press, 37-60.

Terävä, E., Virtanen, P., Uusikylä, P. \& Köppä, L. (2011) Vaikeasti työllistyvien tilannetta ja palveluita selvittävä tutkimus. Työ- ja elinkeinoministeriön julkaisuja. Työ- ja yrittäjyys 23/2011. Helsinki.

Toivanen, M., Väänänen, A., Kurki, A.-L., Bergbom, B. \& Airila, A. (2018) Moni osaa! Työpaikkaosaaminen monikulttuurisilla työpaikoilla. Helsinki: Työterveyslaitos. http://urn.fi/URN:ISBN:978-952-261-803-0 
Tuomi, J. \& Sarajärvi, A. (2002) Laadullinen tutkimus ja sisällönanalyysi. Helsinki: Tammi.

Työsopimuslaki 26.1.2001/55. https://www.finlex.fi/fi/laki/ ajantasa/2001/20010055

Verwiebe, R., Seewan, L., Wolf, M. \& Hacioglu, M. (2016) "I have to be very good in what I do". Marginalization and discrimination in the career-entry phase experiences and coping strategies among university graduates with a migrant background in Austria. Journal of Ethnic and Migration Studies 42 (15), 24682490. https://doi.org/10.1080/1369183X.2016.1169160

Wrede, S. (2010) Etnistyvä eriarvoisuus ja keinot kohti tasa-arvoa. Teoksessa S. Wrede \& C. Nordberg (toim.) Vieraita työssä: Työelämän etnistyvä eriarvoisuus. Helsinki: Helsinki University Press.

Yhdenvertaisuuslaki 1325/2014. https://www.finlex.fi/fi/laki/ alkup/2014/20141325

Yijälä, A. \& Luoma, T. (2018) "En halua istua veronmaksajan harteilla, haluan olla veronmaksaja itse": Haastattelututkimus maahanmuuttajien työmarkkinapoluista ja työnteon merkityksestä heidän hyvinvoinnilleen. Tutkimuksia 2018:2. Helsingin kaupunginkanslia. https://www.hel.fi/hel2/ tietokeskus/julkaisut/pdf/18_06_20_Tutkimuksia_2_Yijala_Luoma.pdf (luettu 29.9.2021) 


\section{Heidi Lehtovaara}

Highly educated female migrants' experiences of discrimination during the job search process

Highly educated migrants face discriminatory treatment, from everyday encounters to the job search phase and working life. Using qualitative research, this article examines the experiences of discrimination and racism that emerged from the data and the strategies described by the interviewees when they faced discrimination and racism. The research is located in the fields of Gender Studies and Working Life Studies. The 12 study participants represent a wide range of migrants from within and outside the EU. Thematic interviews were conducted and the findings were analysed with content analysis. The results of the study show that experiences of discrimination complicated and prolonged the job search process. Discrimination and racism were present even before the actual job search process. The strategies employed in the face of discrimination and racism varied individually and from situation to situation. The protracted job search process and the discriminatory treatment that made it difficult had negative consequences for the individual's wellbeing, employment, and career development. The article concludes with suggestions for development through which discrimination in the recruitment phase can be reduced. 